\title{
Learning by Doing Intervention: Addressing Phonological Difficulties of Children through Audiolingual Method and Total Physical Response
}

\author{
Edgar Lester Romupal, Carla Marie Rubio, \& Cathy Mae Toquero \\ Mindanao State University, General Santos City, Philippines \\ cathymaetoquero@gmail.com
}

\section{ARTICLE HISTORY \\ Received : 12 May 2021 \\ Revised : 21 May 2021 \\ Accepted : 14 September 2021}

\section{KEYWORDS}

Phonological Awareness Audiolingual Method Total Physical Response Alphabetic Principles Learning by Doing

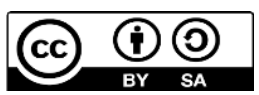

\begin{abstract}
Phonological awareness is a critical skill that children must master during the early foundations of literacy. It is considered a highly accurate predictor of a child's success in learning to read. However, at the expected age, there are cases in which children have not developed phonological awareness that consequently result in poor reading skills. This case study sought to determine the alphabet knowledge of two seven-year-old children and address their difficulties in phonological awareness through the alphabetic code. The researchers conducted ten sessions of phonological interventions to children with identified language learning difficulties in reading. The data analysis and collection process included curriculum document reviews, diagnostic assessments, phonological interventions, and evaluation. Diagnostic results indicated that the children have difficulties in letter recognition of Consonant-Vowel-Consonant (CVC) patterns, blending, and segmentation of phonemes. However, anchoring on the principles of learning-by-doing delivered through oral-situational as a core language approach, the interventions in this case study were found effective for phonics instruction. The audiolingual method and the total physical response in learning phonics, or letter sounds, activated children's basic phonological skills. Repetition, drilling, memorisation and performing language or vocabulary concepts using physical movement to react to verbal input can lessen the phonological difficulties of children. In light of the current global situation, no previous studies have applied a case study utilizing both audiolingualism and total physical response to address the phonological issues of non-readers. Hence, this study offers scientific and pedagogical implications.
\end{abstract}

\section{Introduction}

The ability to read is deemed as one of the important indicators to academic success. In early literacy, reading is the foundational skill that children must develop. However, there are cases where children have struggles in reading due to developmental delays in language (Wolk, 2015; Choo, 2019), including phonological awareness. Phonological awareness is a critical skill that children need to master as it is a predictor of children's success in learning to read (Moats \& Tolman, 2009). Therefore, phonological difficulties should be addressed through appropriate language interventions.

According to the released Global Education Monitoring Report (UNESCO, 2014), 250 million children worldwide cannot read, with 130 million of them in primary school and these prevailing reading problems (Vilsack, 2014) on reading are attributed to the learners' lack of mastery of the alphabetic principles and phonological awareness. Lonigan et al. (2000) verified the role of alphabet knowledge and phonological awareness in forecasting subsequent reading achievement in children. These two domains have been verified as a vital component of children's emergent literacy proficiency (Coursin, 2012). The assessment of these domains plays an important role in the management of children at-risk for poor reading outcomes. Focusing on alphabetic principles along with phonological awareness is crucial to address the reading problems in later life of the children.

The ability of a child to recognize and name letters is referred to as alphabet knowledge (Kleeck, 1990). The alphabetic principle holds that letters and groups of letters represent spoken language sounds. Readers gain access to the alphabetic principle through phonics when they apply their knowledge of sound and letter relationships to familiar or unfamiliar words. Likewise, phonological knowledge as a central phenomenon plays a critical role in the growth of reading and writing capacities and processes of the children (Grofćíková \& Máčajová, 2017). Phonological awareness indicates that the area of oral language relates to the ability to think about the sounds in a word (the word's phonological structure) rather than just the meaning of the word (Mohammed, 2014). These concepts are foundational skills for children's ability to read.

Through an oral-situation approach in language teaching for struggling readers, it is a plausibility to address the issues on the two domains. It is deemed to be the feasible and effective approach since children are expected to respond in situations provided to them. Active response and input are 
perceived when children are engaged in situations where they can connect and relate. Oral-situation approach was pioneered by British applied linguists in the 1920s and into the 1960s (Smith \& Loewen, 2018). The oral-situational approach is called for structuring systems around situations that allow the learner to practice the target language with maximum opportunity (Murcia, 2014).

In addition, UNICEF (2018) strengthened the claim that play is one of the most important ways in which young children gain essential knowledge and skills. For this reason, play opportunities and environments that promote play, exploration, and hands-on learning are at the core of effective pre and during primary programmes. According to the organisation, six to eight years old are often considered the early grades of primary school. Play-based learning continues to be critical, but it is often neglected in favour of academic-focused education approaches. However, in this period, active, play-based learning approaches can transform the educational experiences of children in the early primary grades and strengthen learning motivation and outcomes. A game-like approach to teaching a foreign language (English) may improve the workings of the mind rather than a clearcut teaching methodology (Cook, 2008).

This study is anchored on the theory of John Dewey about activity-based learning and child-centred instruction and his famous educational mantra "learning by doing" (Sadi \& Cakiroglu, 2011). Learning by doing is the process whereby people make sense of their experiences, especially those experiences in which they actively engage in making things and exploring the world (Bruce \& Bloch, 2012). Consequently, Physical Response and Audiolingual Method are mainly used in the study. These language methods elicit participation and responses from the children to engage in an active learning process and environment. Through these approaches, children are the main actors of learning, activating their senses to learn by doing.

Specifically, one known language technique is the Total Physical Response (TPR). Total Physical Response, as a teaching technique, allows learners to respond physically to instructor's directives, teach language by physical (motor) movement, and proper setting and going right into the exercises section that improve student comprehension in reading procedure text (Zulpan, 2018). It was originated by James Asher in the 1960s and managed to create instructional methods in the 1990s (Shi \& Ariza, 2018). Hence, explicit phonics instruction coupled with extensive practise are pertinent to children's mastery of alphabetic principles and phonological awareness.

Another possible method is the Audiolingual Method. The founders of the Audiolingual Method (Fries \& Lado, 1958) wrote that language learning is a mechanical habitforming mechanism. Imitation and repetition allow this development. Therefore, this method emphasises aural training, followed by pronunciation training, listening, reading, and writing (Mei, 2018). Audiolingual Method focuses on language learning by listening to and repeating (speaking) dialogues and exercises in the target language, which is often specified by an idealised native-speaker standard (Rilling, 2018).

As previously stated, reading is a crucial ability for children to succeed academically. Children can develop their capacity to read at an early age if they are provided with reading opportunities. However, the situation of the children in this case study is not true for all children, since only certain children experience delays and difficulties, including phonological difficulties. Well-developed methods and interventions should be employed to address the difficulties of these children and prevent more complex and pressing developmental and academic issues. In the Philippines, the findings of a 2019 study conducted by the Department of Education (DepEd) reported that more than 70,000 elementary students in Bicol cannot read in both English and Filipino (Jaucian, 2020). Moreover, Filipino students manifested signs of academic performance problems in the 2019 Programme for International Student Assessment (PISA) results. Specifically, the Philippines was ranked at the bottom in reading literacy with 340 points out of 79 countries that were assessed (OECD, 2018). The results strongly suggest that Filipino learners confront challenges in their early schooling years, especially in reading skills that affect their academic performance in the latter years.

To render remediation to the existing issues, this study sought to determine the phonological awareness of Filipino children and create language learning interventions to address their difficulties in mastering alphabetic principles and phonological awareness.

Before the emergence of the COVID-19 pandemic, related studies on TPR investigated it as a language learning tool to concentrate on vocabulary mastery (Ekawati, 2017; Khakim, \& Anwar, 2020) and teaching listening (Englishtina, 2019). Previous studies on ALM, on the other hand, discussed how it can address students' speaking skills (Aprianto, Ritonga, Marlius, \& Nusyur, 2020), grammar (Maaliah, Widodo, \& Aziz, 2017; Vidhiasi \& Lengari, 2018), and second language acquisition (Tassev, 2019). Likewise, recent studies (Aprianto et al., 2020; Wullur et al., 2021) on ALM and TPR were applied separately as language learning and vocabulary learning interventions through a quasi-experiment on college and senior high students.

Corollary, the researchers have found out the existing gap that no studies regarding the combination of Total Physical Response (TPR) and Audiolingual Method (ALM) as language learning interventions were done during the pandemic as distance learning is implemented in schools. The aforementioned studies on the two language learning methods also lack data on phonological difficulties, which are deemed crucial in the early literacy of children. This study therefore addresses the missing link between theory and practice in the fusion of TPR and ALM to address phonological difficulties among children, especially at the time of a global health crisis. 
This research also characterizes originality since we combined two strategies as applied through a case study with elementary learners who are struggling readers. Since we wanted to conduct an in-depth examination and provide phases of interventions to address the phonological difficulties of the said learners, then we deemed case study as suitable for the investigation.

\section{Literature Review}

There have been a number of definitions of phonological awareness proposed, each with well-developed theoretical underpinnings and empirical evidence. Phonological awareness is distinguished by the task performed and the size of the unit of sound that is the focus of the task. Blending sounds together, breaking (segmenting) words into their constituent sounds, recombining sounds of words, and assessing if two words have certain sounds in common are examples of diverse phonological awareness capabilities that are defined by the type of task done (Anthony \& Francis, 2005). Phonological awareness is a broad term that spans a wide range of abilities. Some skills show simple, shallowlevel phonological awareness, while others show complicated, deep-level phonological awareness (Justice \& Schuele, 2004). All of these abilities, however, appear to be based on the same information foundation (Anthony \& Lonigan, 2004; Anthony et al., 2002; Schatschneider, Francis, Foorman, Fletcher, \& Mehta, 1999). Simple phonological awareness activities, such as breaking words into syllables, finding and producing rhymes, and matching words with the same initial sound, are examples of shallowlevel knowledge.

At a higher degree of phonological awareness, the capacity to identify and manipulate particular sounds or phonemes is required; this talent is known as phonemic awareness. This higher degree of phonological awareness, or phonemic awareness, has been found to be directly associated to early word decoding ability (Anthony \& Lonigan, 2004; Ball \& Blachman, 1991; Torgesen, Morgan, \& Davis, 1992; Wagner \& Torgesen, 1987; Wagner, Torgesen, Laughon, Simmons, \& Rashotte, 1993). Phonological awareness testing in preschool and kindergarten gives crucial information on the strategies that children use to learn to read (Adams, 1990).

When compared to several other predictors of later reading, Lonigan, Burgess, and Anthony (2000) found that phonological awareness was the steadiest and most robust indication of later reading in a cohort of children tracked from late preschool to kindergarten and first grade.

Moreover, Total Physical Response (TPR) is based on a combination of speech and action that focuses on teaching language through physical exercise (Wang, 2017). According to Asher (1982), the one who developed the method, TPR is based on the premise that the human brain is naturally conditioned to learn every natural language within interaction. The process of learning a second or foreign language is internalised as the process of learning a first language, allowing for a lengthy period of listening and gaining understanding prior to processing. Errors are allowed at the outset of the learning process. Along with deepening language skills, the instructor can gradually interfere and correct learner's errors so that learners can make more fine-tuned phrases (Qian, 2014).

TPR also aids students' memory growth in speech development since a word is easier to understand and use (recalled) if the learner has direct experience with it (Nasution, 2009). Sayd (2018) also added that the method can enhance children's speaking and language skills as it uses simple language, incorporates elements of game movement, and provides a facilitative learning environment. Foreign language learning is analogous to first language learning and reflects comparable naturalistic processes, according to Asher (1977). TPR exercises, according to him, have an interaction efficacy in the realistic classroom between teacher-student and student-student. Learners' anxiety levels may also be reduced to those of a more natural situation, allowing them to feel less threatened in the language classroom (Asher, 1981). TPR also creates a stimulating environment by enabling children to join and become involved in activity, which boosts their excitement by allowing them to move freely. TPR students learn the language in a friendly and pleasant setting (Larsen-Freeman, 2000).

A study of Shan-Shan (2017) compared the TPR and traditional teaching method in teaching Primary English. Results revealed the advantages of TPR as it stimulates pupils' enthusiasm for English class, improves the efficiency of English teaching, increases pupils' English interest, motivates their creativity, and provides a relaxing atmosphere.

Lewis's recent study (2020) examined how physical motions may help first-graders improve their letter-sound identification for short vowels. Total Physical Response was employed in the study. The teacher demonstrated the letter motions, which the pupils subsequently practiced and utilized in other tasks. As a result, the use of physical movements and phonics training for letter-sound identification for short vowels increased the scores of four out of five students, demonstrating a favorable link between the use of physical movements and phonics training for letter-sound recognition for short vowels. One student did not improve on his assessment, portraying that this strategy did not correlate to an improvement in letter-sound correspondence for short vowels.

Focusing on concept of Audiolingual Method, Lado (1978) coined the word "Mim-Mem" to describe the Audiolingual Method, which he described mimicry and memorisation as methods to improve language automaticity. Based on structural linguistics and behavioural psychology, Audiolingual Method follows different kinds of drills (Chunsuvimol \& Charoenpanit, 2017). The audiolingual method helps students react correctly and rapidly in exchanges of conversations both within and outside of the 
classroom (Harmer, 2001). The approach is focused on the idea that learning the English language through speech is more successful than learning it through text. Dialogue has an imperative role in the method as it enables students to practise memorising, mimicking, and speaking English (Bagheri, Hadian, \& Vaez-Dalili, 2019). As supported by Butzkamm and Caldwell (2009), dialogues harness learner's language fluency and agility. The use of ways to develop learners' speaking skills is not separate from the use of techniques (Taufiq, 2018).

According to Effendy (2009), using audiolingual methods of language learning will improve students' ability to recite letters, increase their ability to create sentence patterns, improve their speech, and make the classroom environment more alive because students are actively responding to learning materials. Drilling is a method that involves repeating vocal patterns and structures (Kartikasari \& Salam, 2015). Drills are regarded as a fundamental aspect in the learning process in systems based on a Behaviourist perspective of learning, such as Audiolingualism. Drills are utilized to support the establishment of beneficial habits in this method, which focuses primarily on the presentation and practice of structures. The most basic exercise for acquiring linguistic patterns is repetition. It is utilized right at the start of a language class. Learners just repeat what the teacher says or what the tape recorder records (Kakunta \& Kamanga, 2020). Last but not the least, a recent study of Sidabutar (2021) investigated the effect of the Audiolingual Method on speaking achievement of second grade students focusing on dialogue, speaking, vocabulary, fluency, and comprehension. Results revealed the students' speaking ability by using the Audiolingual Method shows better results compared to those who did not teach by using the said method.

\section{Method}

\subsection{Research Design}

This study strives to determine the phonological awareness of children and create language learning interventions to address their difficulties in alphabet knowledge and phonological awareness. Hence, the researchers employed a single case study. Case studies explore and investigate contemporary real-life phenomenon through detailed contextual analysis of a limited number of events or conditions, and their relationships when a holistic and in-depth investigation is required (Zainal, 2007).

\subsection{Case Participants and Ethical Consideration}

With respect to the rules and to maintain the confidentiality of the subjects, the children are named as Brigh (pseudonym) and Sofianne. Brigh (male) and Sofianne (female) are both seven-year-old Grade Two students who came from two public schools in General Santos City, Mindanao, Philippines. They both have difficulty in reading and weaknesses in alphabet knowledge and phonological awareness. In terms of the process of intervention, the researchers asked for the permission of the guardians of the children to allow them to choose their children for the case study. They were told of the nature of the study and its purpose. The children showed willingness to learn to read together with the researchers. The researchers' served as facilitators to the teaching and learning intervention process.

\subsection{Case Description}

Brigh is under the custody of his grandparents due to family issues. Brigh is continuing his studies despite the pandemic. He is under modular classes or with the utilisation of the modules provided by the school as learning modality. Brigh grew up in a community that can be considered a "suburban" community. He is an active child who loves to play with his friends. Based on the conversation with his grandparents, Brigh has been doing and answering his modules rarely. His grandparents are not able to teach him and offer assistance regularly because they are busy making a living. Brigh lack support when it comes to his learning. Additionally, the grandparents stated that they were unable to devote their full attention to Brigh's studies due to a lack of time and that they were unsure how to teach him the mod ules' lessons because they do not understand how they shoul $\mathrm{d}$ be taught properly or how to provide the answers.

In the case of Sofianne (pseudonym), she is already delayed in the progression since she still has the difficulties in identifying the sounds of the letters that is a contributory factor to her difficulty in reading. Sofianne is a seven-yearold Grade Two student. She is the eldest among her two siblings (three-year old boy and eight months newborn baby). Both her parents are businesspeople. Based on the researcher's observation, Sofianne is a jolly and outgoing child. She loves to watch vlogs and nursery rhymes through YouTube. Grounded on her mother's narratives, she does not usually spend time playing with physical toys and enjoys more of her attention on mobile phone and tablet. She is currently on a distant learning setup with modular activities.

\subsection{Digital and Non-Digital Interventions}

Both digital and non-digital teaching methods and instructional resources were used to assess the complexity of the lessons. In addition, the tools are being modified and dependant on the current instructional resources. In terms of multimedia educational content, video presentations such as those featuring letter sounds or phonics, as well as videos containing explanations about rhyming words and nursery rhyme videos were utilised in testing the difficulty. The researchers included non-digital teaching resources or objects such as worksheets with simple Consonant-VowelConsonant (CVC) words, a worksheet with poetry and lyrics to songs with rhyming words, and a writing board. Also, the researchers as facilitators used real objects (i.e., rhyming pairs objects), rhyming sort task cards template, and a big table template where the child posted the cut-outs from the template based on their answers on the rhyming sort task cards. The researchers made the task of separating rhyming words from non-rhyming words more playful by 
incorporating it into an active play using the materials described above. The researchers applied a combination of learning tools to create the process for intervention in addressing the difficulties of the children in alphabet knowledge and phonological awareness.

\subsection{Collection and Analysis Protocol}

The researchers' conducted a field observation to gather the data. Observation and scaffolding for the children were also evident in the course of this case study. The researchers utilised field memo strategy to keep track of the learning process and things needed for the improvement of the children. An outline learning plan was created as a blueprint for the flow interventions utilised for the entire sessions. Document critical analysis, participant observation, pretest, posttest, and triangulation of multiple sources allowed interpretations for data analysis.

The researchers started to interview the guardians of the children to have a background about the life of the children. The researchers made an observation of the situation of each child. The researchers first established a relationship with the children so that they would be comfortable during the entire learning process. The researchers and the children started the process by having interaction with each other.

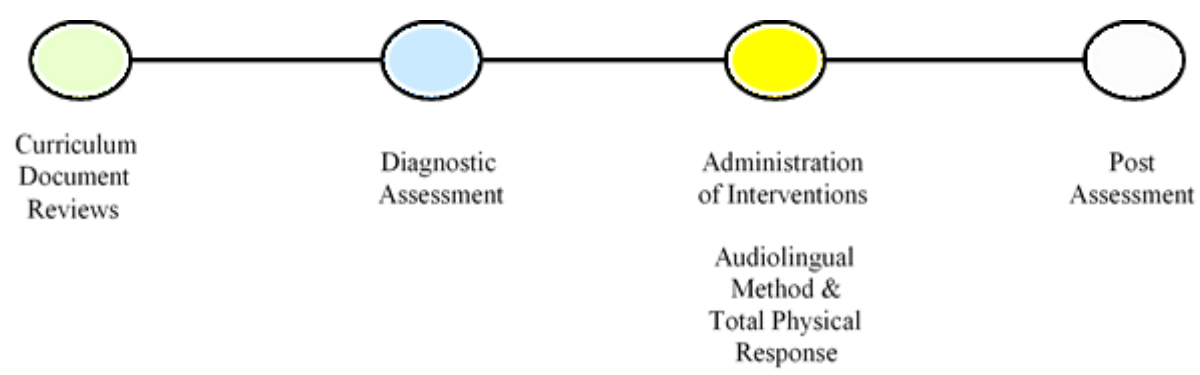

Figure 1. Stages of Collection and Analysis

Figure 1 shows the stages of collection and analysis of this case study. A review of the curriculum competencies was done followed by a diagnostic assessment of the phonological-related competencies of the children. To address the difficulties of the children based on the assessment results, an intervention was done employing both the Audiolingual Method and Total Physical Response. Thereafter, a post-assessment was carried out to test the progress of the children and whether the learning-by-doing intervention was effective.

\subsection{Curriculum Document Review}

Two of the content domains in the $\mathrm{K}$ to 12 Curriculum Guide of the Department of Education in English are alphabet knowledge and phonological awareness. The specific areas or English lessons tested on this case study were based on the English Curriculum Guide and those were to identify sounds, recognise rhyming of words in nursery rhymes, poems, songs heard, and distinguish rhyming words from non-rhyming words. In Grade 2 content standard under alphabet knowledge, it states the learner demonstrates understanding of the alphabets in English in comparison to the alphabets of Filipino and Mother Tongue. Under phonological awareness, the content standard states that the learner demonstrates understanding of the letter-sound relationship between Mother Tongue and English for effective transfer of learning.
Table 1. Objectives of the Learning Plan for this Study

\begin{tabular}{|c|c|}
\hline Objective 1 & reads the alphabets of English; \\
\hline Objective 2 & $\begin{array}{l}\text { recognises names of people, objects, things, } \\
\text { and places; }\end{array}$ \\
\hline Objective 3 & $\begin{array}{l}\text { produces speech sounds (sounds and letter } \\
\text { names); and }\end{array}$ \\
\hline Objective 4 & $\begin{array}{l}\text { reads words with short sound in } \mathrm{C}-\mathrm{V}-\mathrm{C} \\
\text { pattern. }\end{array}$ \\
\hline
\end{tabular}

Table 1 shows the objectives under the domain and the grade level based on the Curriculum Guide of English duly issued by the Department of Education. The researchers identified the letter and sound of the names of people, objects, things and places (noun) in $\mathrm{C}-\mathrm{V}-\mathrm{C}$ patterns.

\subsection{Language Approach and Language Learning Methods}

The researchers used the Oral-Situational Approach complemented with Audiolingualism. Before learning how to write the content, learners must first learn how to read it. The core approach was appropriate in the case study since the children were able to learn first the letter sounds which were performed orally before learning how to read words and how to eventually write words. Systematic teaching using this approach is crucial to learning since language teaching is based on expression, structures, and an emphasis on a selection of common vocabulary items (Rhalmi, 2009). 
Moreover, the use of scenarios and repetition were evident in teaching reading. The researchers made a connection between the circumstances that might represent and resemble the lesson accompanied with various materials. Furthermore, the children learnt by repetition. The researchers believed that to enable the child to improve and to learn, situation presentation and practice of words are both necessary. The approach was delivered through Audiolingual Method and Total Physical Response as interventions.

\section{Results}

\subsection{Preliminary Investigation Protocol}

Based upon the conducted preliminary observation of the researchers with the children, it showed that Sofianne did well in comprehending a story if it is presented with visuals and videos. The facilitators gave assistance through giving questions. The facilitators also found out that the Brigh did well when it comes to comprehending a story if it is presented with visual presentation and when the facilitators offered assistance on stimulating the mind of the learner by asking what happened in the story. They can understand what is happening in the story with the scaffolding strategy. However, with the use of variety of instructional materials, the facilitators discovered that Brigh and Sofianne did not know how to read. The children cannot utter a single word from the passages, stories, or even from short phrases.

When it comes to reading a sentence, CVC word, story, or a short passage, both children were not able to read and utter even a single word. The children did not know how to read words. They had difficulty in reading the phonemes. Both children were not able to read because they cannot identify letters and pronounce the sounds of the letters. They lack mastery of alphabetic knowledge and phonological awareness.

\subsection{Diagnosing Phase}

During the administering of the pre-test which was conducted during the first session (Phase 1), the researchers utilised an oral test in which the children were asked to identify the letter, produce the sound, and read C-V-C word patterns (Figure 2). After administering the pre-test and determining the current English Language standing of both children, it can be diagnosed that their weaknesses on English Language skills were on alphabet knowledge and phonological awareness. They cannot read words with three letters (C-V-C patterns) at the age of seven. They have difficulty in identifying letters and the sounds that consequently contributed to their reading difficulty.
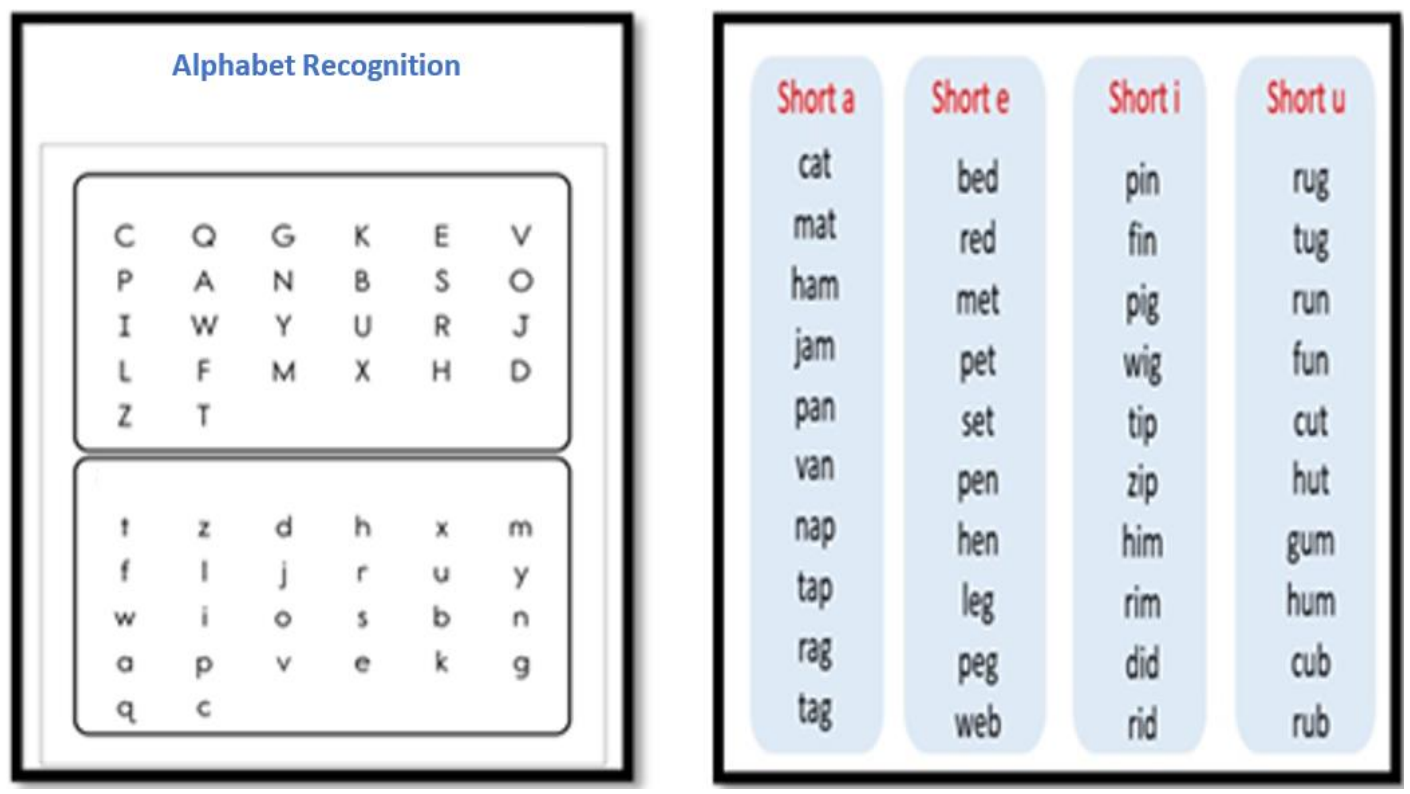

Figure 2. Alphabet Chart and CVC word bank used in Pretest

The results revealed that the children have generally poor alphabet knowledge and phonological awareness. In the first test, they have very few correct responses out of twenty-six alphabets. The second test, on the other hand, showed their inability to read an entire word. They can only produce the sounds of the beginning letters, but not all and only with the guidance of the tutors. Sofianne and Brigh also mistakenly produced the name of the beginning letter, instead of the sound.
The researchers discovered that both children did not know how to properly utter the sounds of the letters. They lack phonemic awareness and cannot produce the sound patterns to produce words. Since the children have poor alphabet knowledge and phonological awareness, they need to identify the letters by naming it and producing the sound. In such method, they can grasp the recognition of letter and sound with the help of their first-hand execution aided by interactive instructional materials and active play. 


\subsection{Experimenting Phase}

Children must have phonological knowledge in order to find a solution to their trouble reading in the English language. The children must return to recognising and understanding letter sounds, or phonics, to recognise rhyming of words in nursery rhymes, poetry, and songs heard, and to differentiate rhyming words from non-rhyming words. Gradually, the children must return to knowing and understanding the letter sounds.
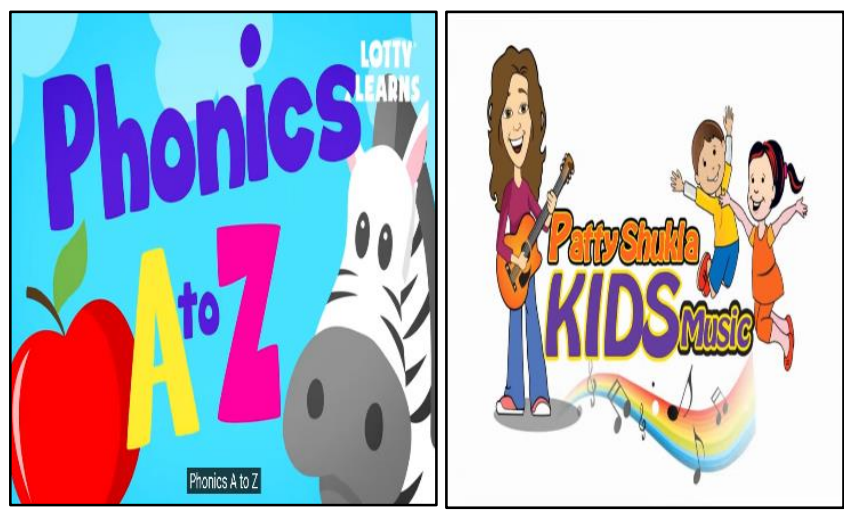

Figure 3. Phonics and Alphabet Songs for Children

The researchers presented videos with the help of digital learning materials, the videos contained tutorials about the sound of the letters or the phonics (Figure 3). The researchers and the children watched the videos repetitively so that the children can familiarise and recognise the sounds of the letters. Then, the facilitators uttered the letters and let each child speak for letter sounds.

In Phase 2, the facilitators utilised several and varying interventions towards the children to experiment and test their learning styles and preferences. First, the facilitators employed a "teacher-led instruction" in which a facilitator leads and talks more, rather than the child. Second, the facilitators utilised the aid of technology by letting the child watch educational videos (specifically nursery rhymes, alphabet songs, C-V-C reading, etc.). Third, the facilitators created flashcards in which the children can manipulate the objects while practising the alphabet identification and speech sounds. The facilitators found out that Sofianne and Brigh respond actively to visual cues in which they can have the verdict to manipulate the objects. Sofianne also enjoyed talking during the instruction since she is an outgoing child.

\subsection{Implementing Phase}

After the experimenting phase and diagnosing the learning preferences of the children, the facilitators implemented three tools that were suited to the learning styles of Sofianne and Brigh.

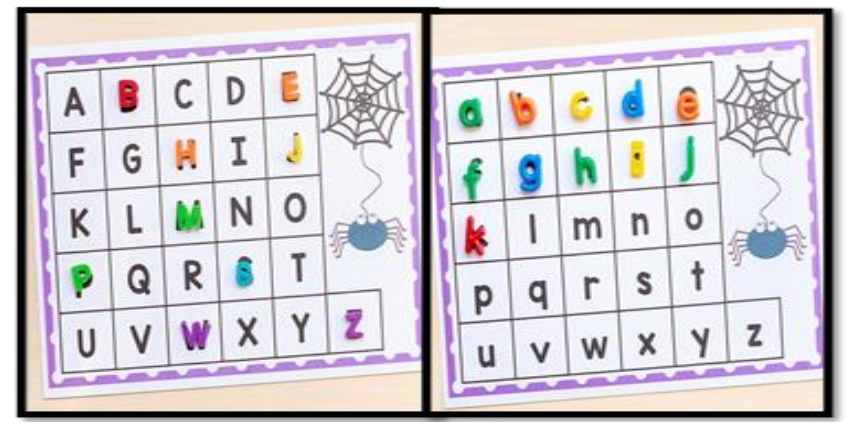

Figure 4. Interactive Board

The first tool that the facilitators used was the interactive board (Figure 4). The board consisted of the English alphabet letters (uppercase and lowercase) in order. There will be a colour code in each letter and a coloured letter. The facilitator reads a specific letter and the child needs to match the uppercase and lowercase letter on the board by referring to the colour code and cover it by the coloured letter. After matching and covering the letter, the child must name the letter and produce its sound.

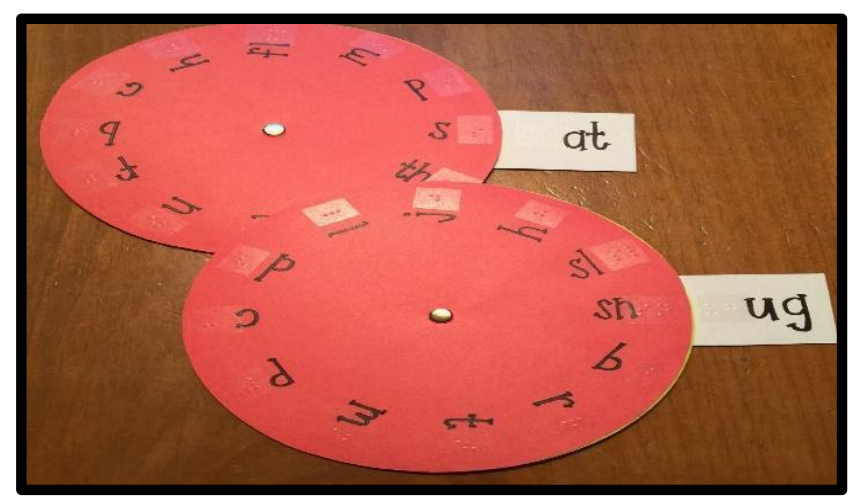

Figure 5. Visual Cue on Blending and Segmenting

The second tool that the facilitators used in the course of observation was the word family spinner (Figure 5) that helped the children recognise patterns among words (specifically the C-V-C), which may increase their alphabet knowledge, including the phonological awareness and accuracy. The facilitator spins the wheel and let the child: (1) determine each letter of the word; (2) perform the individual sounds of the word; and (3) read the entire word.

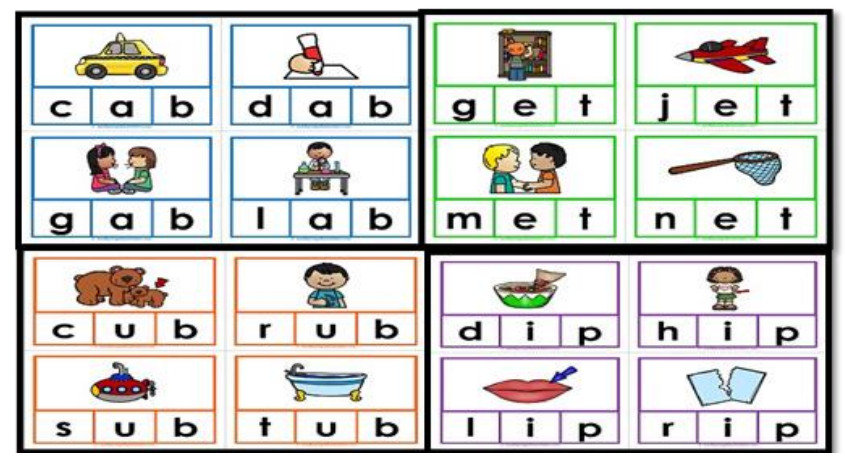

Figure 6. Visual Cue on Blending and Segmenting 
The third tool was a visual cue on blending and segmenting the sounds (Figure 6). The cards have pictures of the word and the letter that forms the word separated each by a block. When blending, the facilitators showed the children how to say the sounds closer and closer together to make a word. When segmenting, the facilitator showed how to stretch the sounds out so they can hear each sound. After the modelling, the children can perform it through repetitions.

In the third phase, the facilitators presented a variety of instructional materials such as presenting short stories in the form of a video with the help of digital learning resources. They were also presented with plain texts, passages, short phrases, and stories to help in determining the strengths and weaknesses of the child.

\subsection{Evaluating Phase}

After the 10-session observation and intervention, the facilitators evaluated the progress or regression of the children's English skills specifically on alphabet knowledge and phonological awareness. Similar tests were given from the pre-test to the post-test. The facilitators evaluated the performance of the children if they improved or only retained their previous situations. Additionally, the facilitators took note of critical aspects and observations that must be taken into account as the children's learning process continues.

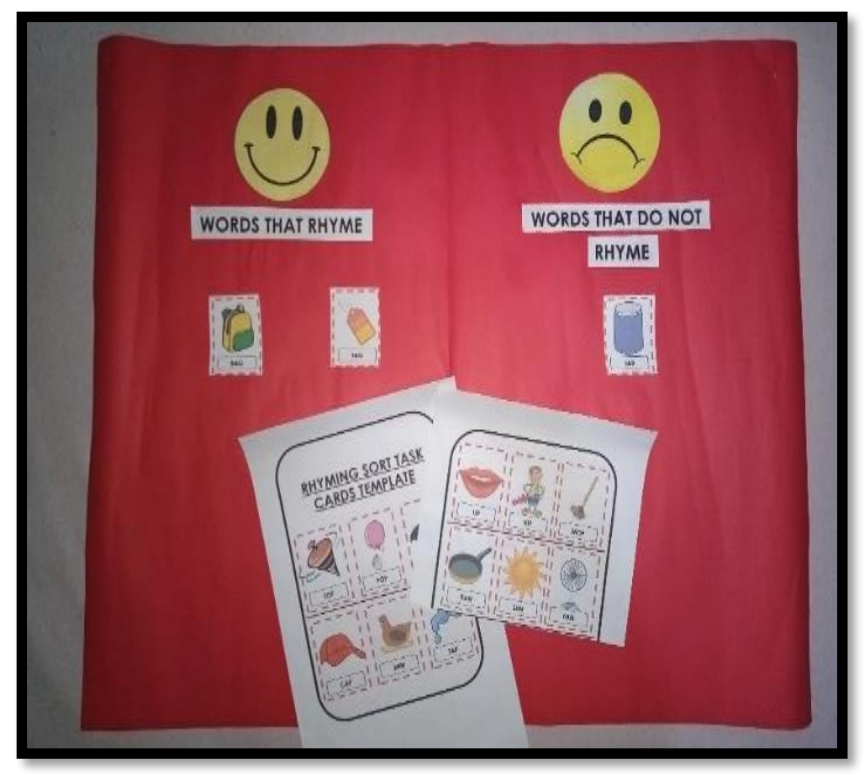

Figure 7. Rhyming Words Worksheet

In the last phase, the facilitators also gave some worksheets containing the basic CVC words (Figure 7). The facilitators assisted the child in reading one by one the various $\mathrm{CVC}$ words, then, each facilitator asked questions to the child about their observations regarding the presented CVC words.

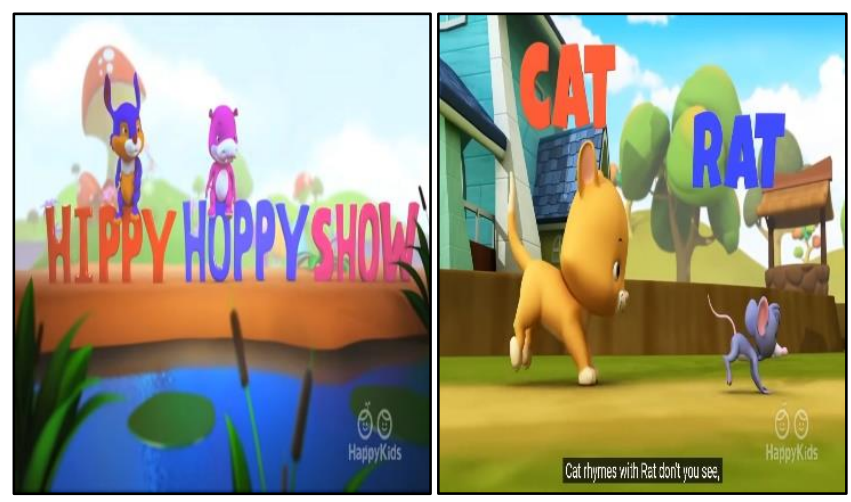

Figure 8. Rhyming Words 3D Nursery Rhymes for Kids and Children

Eventually, the children recognised some rhyming words that were present in the CVC worksheet. The facilitators also presented videos that explain the rhyming words (Figure 8). After that, the facilitators elaborated and explained it to the children.

In the last phase, the children can recognise rhyming words. The facilitators provided videos (nursery rhyme videos), songs, and poems that contain rhyming words and asked the child to determine the rhyming words on the presented videos, songs, or poems. The facilitators also provided an active play about distinguishing rhyming words from non-rhyming words.

After giving various instructional materials through the application of audiolingual and total physical response interventions to the children, they were able to recognise phonemes. Sofianne was able to recognise the sounds of the letters little by little as the days passed. Brigh was able to recognise the letters of the sounds. Eventually, he was able to read basic CVC words by incorporating the sounds of the letters. With the assistance of the facilitators and through teaching children to utter the sound of the letters then connect it to the sounds of the other letters in the words, they were able to decode phonemes.

Each child was able to read simple and basic CVC words. As the sessions passed, the children identified the rhyming words from the instructional materials presented (digital and non-digital) and eventually they can distinguish the rhyming words from the non-rhyming words. The facilitators made some realisations along the process of the interventions. Facing some difficulties and situations together with the children also helped the facilitators to realise possible ways to make the interventions work according to the learning styles of the struggling readers.

Moreover, after 10 sessions of intensive intervention, the children showed a positive outcome as they were able to recognise basic sounds of the letters and read simple and basic CVC words. They can recognise the rhyming words from the CVC words presented and from the audio-visual media that was shown. The children can distinguish the rhyming words from non-rhyming words. 


\section{Discussion}

After the rigorous implementation of the interventions and tools, a noticeable improvement can be explicitly seen in letter and sound identification. Both children in this case study can identify the letters and sounds. In the first test, the children manifested signs of improvement from few correct responses in the pre-test to fourteen and more correct responses in the post-test out of twenty-six alphabets. In the second test, the children still cannot read the entire word since they need continuous modelling and guidance. However, their errors in stating the name of the beginning letters were minimised. Both children need the guidance of older peers, teacher, cousin, etc., to read and model the sounds. Both of them need the utilisation of mimicry to perform the speech sounds. With that, it only demonstrates that both learners need support or assistance during their learning process. This support or assistance is referred to as scaffolding. Scaffolding is a form of support that is contingent, fading, and intended to transfer the responsibility of a learning performance or task to the learners (Van dae Pol aet al. 2010). The emergence of scaffolding as an effective instructional tool has highlighted its critical role in assisting students in achieving academic success (Hong \& Nguyen, 2019). With that, providing a supportive learning environment or assistance for the children will allow them to absorb knowledge, have continuous learning progress, and eventually obtain the desired objectives.

After the reflected results in the post-test, the Audiolingual and Total Physical Response methods applied through the interactive board, word family spin, visual cues on blending and segmenting, and digital tools are effective with slight changes and improvement in the alphabet knowledge and phonological awareness of the children. The Audiolingual and Total Physical Response methods are responsive as phonological awareness intervention specifically in learning phonemes or letter sounds. The Audiolingual and the Total Physical Response methods provide a significant contribution to English instruction. These two approaches are a set of strategies that can be combined with other methods to provide effective instruction (Wang, 2017).

Initially, since the children did not know how to read and were unable to utter a single word, the researchers decided to begin teaching the children with the letter sounds or phonics. Phonics is an integral aspect of language learning because it allows learners to understand the connection between letter type and speech tone, which leads to language literacy (Ren \& Ma, 2017). Also, learning more about phonics assists learners to read more quickly and recite what they've just read out (Carley, 2018). Moreover, learning phonics or the letter sounds is being applied with the audiolingual method since it provides repetitions, memorisations, and drills using audio-visual media. In audiolingual method, skills are in sequence: listening, speaking, reading, and writing. Along the process, the children were taught first of sounds of phonemes, and the facilitators assisted the children recognise the phonemes. The Audiolingual Method posits that students can overlearn the language to communicate using exercises and mim-mem tasks. The Audiolingual method attempts to improve students' communicative skill through conversations (Mart, 2018). For audiolingualists, the most critical outcome of the teaching-learning process is to assist learners in understanding the grammatical forms of the target language, which will enable them to use the language more automatically and therefore more effectively (Saricoban, 2004). The facilitators played an important and constructive part in the Audiolingual method, so a collaborative effort occurred between facilitators and learners. They manage content, learn at a regular pace, and keep track of students' progress (Richards \& Rodgers, 2001). Teachers are highly urged to support and assist students who are learning English by repeatedly repeating the right vocabulary, phrases, and sentences (Harmer, 2007).

On the other hand, Total Physical Response is also used since it is a method wherein the child is a listener and a performer. "Total Physical Response (TPR) is a language teaching method built around the coordination of speech and action; it attempts to teach language through physical (motor) activity" (Richards \& Rodgers, 2001, p. 87). In this method, the child is not only a listener or a receiver of the information. Instead, the child learns through listening and at the same time through performing. Additionally, Total Physical Response aids children's cognitive development by stimulating all of their senses, as well as their imagination and creativity (Hounhanou, 2020). Nuraeni (2019) found that after using the Total Physical Response (TPR) method, pupils' vocabulary and comprehension scores improved. The method promotes self-confidence, imagination, interest, and motivation in students. It encourages learners to be engaged, focused, and interactive in the learning activities. Also, the Total Physical Response (TPR) method made the teaching and learning process more flexible and entertaining. As a result, the study demonstrates that using the Total Physical Response method is effective.

Furthermore, the methods employed by the researchers were based on the idea of "learning by doing" by John Dewey. It involves active play while learning. Active play or play-based learning allowed the both children to participate in activities that will enable them to simulate situations they are likely to experience (Ali et al., 2018). At the age of seven, children have a limited attention span. Catching and recapturing a child's attention continuously throughout a lesson is a constant challenge for people who work with young learners, especially those aged 5 to 7 years (Millares, 2012). As a response, the activities given to children must be interactive. Over the course of 10 sessions, the children did not feel a sense of fear and anxiety which fully enabled them to identify the names and sounds of the letters and read the entire word. Moreover, the active play reduced the stress and pressure on the subjects which improved their alphabet knowledge and phonological awareness. While playing, the children were learning consciously and unconsciously. 
In addition, the interventions were effective because the instruction was not teacher-dominated. Both methods helped the children practise the identification of letters and utterance of sounds as first-hand experiences. Intimidation and superiority are also lessened because the facilitators encouraged the children to participate and execute without the fear of committing mistakes and errors. In entirety, the methods are effective because these are learner-centred. In learner-centred teaching, students are in control of their learning. It encourages students to engage actively in the teaching and learning process rather than the more conventional passive role (Darsih, 2019). Negative conceptions, including fear, anxiety, and intimidation, are minimised since the participants are deemed to be the protagonist of the process. The researchers acted as facilitators. In reroute, the learners were not passive receivers of information; instead, they were active enablers of their learning.

The research novelty of this work is the mixture of phonological interventions, specifically the Audiolingual Method (ALM) and the Total Physical Response (TPR), via a case study on elementary learners, to address non-reader challenges during the pandemic. Recent studies on the aforementioned teaching strategies were applied separately as language learning and vocabulary learning interventions. Studies (Aprianto et al., 2020; Wullur et al., 2021) have examined the Audiolingual Method's effectiveness in boosting the vocabulary of English-first language learners and in raising the learners' willingness to learn English. On the other hand, Santika et al. (2020) intended to ascertain the effect of the Total Physical Response (TPR) strategy on Senior High School students' speaking abilities. Nonetheless, these studies placed more importance on a single method as applied to speaking or vocabulary learning rather than on reading instruction. Thus, this study is unique as it integrates two teaching strategies, namely the Audiolingual Method (ALM) and the Total Physical Response (TPR), to address the children's phonological difficulties. Additionally, this study applied stages and phases in the data gathering, analysis, and intervention processes, to arrive at a more detailed and systematic investigation.

\section{Conclusion}

This study has shown that the primary approach which is oral-situational complemented with Audiolingual Method (ALM) and Total Physical Response (TPR) interventions can help the children in coping up with their difficulty in phonology. This mixture of phonological interventions on a case study on elementary learns is the uniqueness of the study, especially since it addresses non-reader challenges during the pandemic. The methods that were used and applied have played a critical role on the learning of the children. With the use of the audiolingual method together given in accordance with their learning circumstances, the children learnt without experiencing boredom. Likewise, the use of Total Physical Response helped the children achieve meaningful learning. They were focused and attentive to what they were learning since they were also entertained. They were able to learn through repetition, drilling, and memorisation.

Although slightly effective, the methods that have been utilised showed effectivity since positive results are observed based on short weeks of intervention. Results revealed that improvement can be seen in children's letter and sound identification along with the ability to produce letter sounds. Negative feelings to learning, including fear, anxiety, and intimidation were minimised as the children enjoyed the play-based activities. Likewise, assistive language interventions can strengthen language learning. Hence, teachers should incorporate "learning by doing" interventions as part of the alphabetic code: (1) audiolingual method and (2) total physical response to address phonological difficulties of struggling readers. Despite these results, this study has its limitations and cannot be generalised to other children due to varying reasons. Since there is a time constraint, full results were not identified and consolidated so the children only showed slight improvements. Likewise, this study only involved two children with unique circumstances to which the interventions may be limited to their context. Nevertheless, the interventions can be administered and sustained by the children's family members and/or personal tutor to scaffold the reading abilities of the learners. Utilisation of various instructional materials considering the oral-situational approach and applied using learning-by-doing principles may attract attention and encourage children to engage in the learning process. Most importantly, a systematic approach to phonics instruction is strongly recommended for teaching children alphabetic knowledge and phonological awareness, with an emphasis on segmenting and blending.

\section{References}

Adams, M. J. (1990). Beginning to read: Thinking and learning about print. Cambridge, MA: MIT Press.

Ali, E., Constantino, K. M., Hussain, A., \& Akhtar, Z. (2018). The effects of play-based learning on early childhood education and development. Journal of Evolution of Medical and Dental Sciences, 7(43), 6808-6811. https://doi.org/10.14260/jemds/2018/0000

Anthony, J. L., \& Francis, D. J. (2005). Development of phonological awareness. Current Directions in Psychological Science, 14(5), 255-259. doi:10.1111/j.0963-7214.2005.00376.x

Anthony, J., \& Lonigan, C. (2004). The nature of phonological awareness: Converging evidence from four studies of preschool and early grade school children. Journal of Educational Psychology, 96, 4355. https://doi.org/10.1037/0022-0663.96.1.43

Aprianto, A., Ritonga, M., Marlius, Y., Nusyur, R. (2020). The influence of using audio-lingual method on students' speaking skill at Madrasah Diniyah Takmiliyah Awwaliyah. Izdihar. Journal of Arabic 
Language Teaching, Linguistics, and Literature, 3(2), 147-160. https://doi.org/10.22219/jiz.

Asher, J. J. (1981). The total physical response: Theory and practice. Annals of the New York Academy of Sciences. 379, 324-331. https://doi.org/10.1111/j.17496632.1981.tb42019.x

Asher, J. J., \& Adamski, C. (1977). Learning another language through actions: the complete teacher's guidebook (vol. 1). Adult Education, Sky Oaks Productions.

Asher, J. J. (1982). Learning another language through actions (2nd ed.). Sky Oaks

Bagheri, M., Hadian, B., \& Vaez-Dalili, M. (2019). Effects of the vaughan method in comparison with the audiolingual method and the communicative language teaching on Iranian advanced EFL learners' speaking skill. International Journal of Instruction. 12(2), 8198. https://doi.org/10.29333/iji.2019.1226a

Ball, E., \& Blachman, B. (1991). Does phoneme awareness training in kindergarten make a difference in early word recognition and developmental spelling. Reading Research Quarterly, 26, 49-66. https://doi.org/10.1598/RRQ.26.1.3

Bruce B.C., Bloch N. (2012) Learning by doing. in: Seel N.M. (eds) Encyclopedia of the Sciences of Learning . Springer, Boston, MA. https://doi.org/10.1007/978-14419-1428-6_544

Butzkamm, W., \& Caldwell, J.A.W. (2009). The bilingual reform: A paradigm shift in foreign language teaching. Tübingen: Narr Studienbücher. https://doi.org/10.1515/9783484431225.152

Carley, H. (2018). Phonics or the alphabet? Which is more favorable for Japanese students who are beginning to study English in a classroom setting. Matsuyama University Studies in Language and Literature, 38, 156-177.

Celce-Murcia, M. (2014). An overview of language teaching methods and approaches. Teaching English as a second or foreign language, 4, 2-14.

Choo, Y. Y., Agarwal, P., How, C. H., \& Yeleswarapu, S. P. (2019). Developmental delay: identification and management at primary care level. Singapore medical journal, 60(3), 119-123. https://doi.org/10.11622/smedj.2019025

Chunsuvimol, B., \& Charoenpanit, P. (May 4, 2017). Effectiveness of the audiolingual method: A further synthesis of research through 2015. https://ssrn.com/abstract=2962925

Cook, V. (2008). Second language learning and language teaching. London, England: Arnold.
Coursin, A. M. (2012). Understanding the development of alphabet knowledge in at-risk populations: The influence of pre-literacy skills [Doctoral dissertation, The University of Wisconsin-Milwaukee]. ProQuest Dissertations and Theses Global.

Darsih, E. (2018). Learner-centered teaching: What makes it effective. Indonesian EFL Journal, 4(1), 33-42. https://doi.org/10.25134/ieflj.v4i1.796

Ekawati, A. D. (2017). The effect of tpr and audio-lingual method in teaching vocabulary viewed from students' IQ. Journal of ELT Research: The Academic Journal of Studies in English Language Teaching and Learning, 2(1), 55-65. https://doi.org/10.22236/JER_Vol2Issue1pp55-65

Englishtina, I. (2019). The use of total physical response (TPR) activities for teaching listening to young learners. Journal of English Language Teaching and Islamic Integration (JELTII), 2(01), 113-120.

Grofčíková, S., \& Máčajová, M. (2017). Abilities of phonological awareness in the context of cognitive development in preschool age. Journal of Language and Cultural Education, 5(3), 46-56. https://doi.org/10.1515/jolace-2017-0027

Harmer, J. (2001). The Practice of English Language Teaching (3rd Edition). Essex: Pearson Education Ltd.

Harmer, J. (2007). The practice of English language teaching. Longman. https://doi.org/10.1093/elt/ccn029

Hong, T., \& Nguyen H. (2019). Teacher beliefs and Practices of scaffolding students' reading comprehension through questioning at pre-reading stage. European Journal of Foreign Language Teaching. http://dx.doi.org/10.5281/zenodo.3270743

Hounahanou, A. (2020). Promoting TPR (total physical response) method in teaching vocabulary for efl beginners in Benin secondary schools. International Journal of Applied Linguistics \& English Literature. http://dx.doi.org/10.7575/aiac.ijalel.v.9n.6p.23

Jaucian, M.B. (2020). 70,000 Bicol Pupils Cannot Read DepEd. Retrieved on March 19, 2021 from google.com/amp/s/newinfo.inquirer.net/1229537/700 00-bicol-pupils-cannot-read-deped/amp

Justice, L., \& Schuele, C. M. (2004). Phonological awareness: Description, assessment, and intervention. Language, Speech, and Hearing Services in Schools. 39. 3-20

Kakunta, K., \& Kamanga, W. (2020). Microteaching: Audiolingual Method. Journal Educational Verkenning, 1(1), 25-30. https://doi.org/10.48173/jev.v1i1.27

Khakim, L., \& Anwar, C. (2020). Improving Students' Vocabulary Mastery Through Total Physical Response Learning Method. Advances in Social Science, 
Education and Humanities Research, 409, 506-512. https://doi.org/10.2991/assehr.k.200225.110

Lado, R. (1978). English series: Teacher's manual 1 (3rd ed.). University of Michigan Press

Lado, R., \& Fries, C. C. (1958). English pattern practices: Establishing the patterns as habits. University of Michigan Press.

Larson-Freeman, D. (2000). Techniques and principles in language teaching. Oxford University Press.

Lewis, J. (2020). Using physical movements to improve firstgrade students' sound-letter recognition for short vowels. https://ursa.mercer.edu/handle/10898/12223

Lonigan, C. J., Burgess, S. R., \& Anthony, J. L. (2000). Development of emergent literacy and early reading skills in preschool children: Evidence from a latent variable longitudinal study. Developmental Psychology, 36, 596-613.

Maaliah, E., Widodo, Y. H., \& Aziz, M. (2017). Using audiolingual method to improve the students' speaking skill. Jurnal Bahasa Inggris Terapan (Journal of Applied English), 3(1), 45-59. https://doi.org/10.35313/jbit.v3i1.1278

Mart, C. T. (2018). The audio-lingual method: An easy way of achieving speech. International Journal of Academic Research in Business and Social Sciences, 3(12), 10-13. https://doi.org/10.6007/IJARBSS/v3i12/412

Mei, Y. (2018). Comments on the Audiolingual Method. International Journal of Arts and Commerce, 7(4), 4753.

Millares, M. (2012). Attention Span: in the 5-to 7-year-old music student. The Free Library. https://www.thefreelibrary.com/Attention+span\%3a+i n+the+5-to+7-year-old+music+student.-a0286390319

Moats, L, \& Tolman, C (2009). Excerpted from language essentials for teachers of reading and spelling (LETRS): The Speech Sounds of English: Phonetics, Phonology, and Phoneme Awareness (Module 2). Sopris West.

Mohammed, F. (2014). The use of phonological awareness skills in teaching phonetics and phonology for university students. IOSR Journal of Humanities and Social Science. $19 . \quad 101-106$. https://doi.org/10.9790/0837-1919101106

Nasution. (2009). Various approaches to the learning and teaching process. Earth Literacy

Nuraeni, C. (2019). Using total physical response (TPR) method on young learners' English language teaching. Metathesis: Journal of English Language, Literature, and Teaching, 3(1), 26-34. https://doi.org/10.31002/metathesis.V3i1.1223
Organization for Economic Co-operation and Development. (2018). PISA 2018 results. https://www.oecd.org/pisa/PISAresults_ENGLISH.png

Ren, H., \& Ma. C. (2017). The Impact of Phonics Instruction on Pre-school Learners' Development in English Language Course. Proceedings of the 2016 7th International Conference on Education, Management, Computer and Medicine (EMCM 2016). Atlantis Press. https://doi.org/10.2991/emcm-16.2017.131

Richards, J. C., \& Rodgers, T. S. (2001). Approaches and methods in language teaching. Cambridge University Press. https://doi.org/10.1017/CBO9780511667305

Rilling, S. (2018). Audio-lingual method. The TESOL encyclopedia of English language teaching, 1-7. https://doi.org/10.1002/9781118784235.eelt0157

Sadi, O \& Cakiroglu, J. (2011). Effects of hands-on activity enriched instruction on students' achievement and attitudes towards science. Journal of Baltic Science Education. 10(2), 87-97.

Santika, A., Aminah, M., \& Sibarani, J. (2020). The Effect of Total Physical Response (TPR) Teaching Method Towards Students' Speaking Skill. Proceeding Seminar Nasional Pendidikan Universitas Subang (SENDINUSA), 2(1), 15-20. http://ejournal.unsub.ac.id/index.php/sendinusa/article /view/952

Saricoban, A. (2004). The Use of Audiolingual Method in Teaching Turkish. Hacettepe Üniversitesi Türkiyat Araştırmaları (HÜTAD), pp. 187-200. https://dergipark.org.tr/tr/download/articlefile/326866

Sayd, A. I., Attubel, M., \& Nazarudin, H. (2018). Implementasi metode total physical response (TPR) dalam pembelajaran bahasa Inggris bagi anak-anak sekolah dasar inpres Liliba Kupang. Bisman-Jurnal Bisnis \& Manajemen, 3(01), 17-24.

Schuele, C. M., \& Boudreau, D. (2008). Phonological awareness intervention: beyond the basics. Language, speech, and hearing services in schools, 39(1), 3-20. https://doi.org/10.1044/0161-1461(2008/002.

Shan-shan, F. (2017). An Application of Total Physical Response to Primary English Teaching-A Case Study of Qingtong Primary School. US-China Foreign Language, 15(1), 36-42. https://doi.org/10.17265/1539-8080/2017.01.006

Shi, Y., \& Ariza, E. (2018, February). A study on the natural approach (NA) and teaching proficiency through reading and storytelling (TPRS). In 6th International Conference on Social Science, Education and Humanities Research (SSEHR 2017) (pp. 405-409). Atlantis Press. https://doi.org/10.2991/ssehr17.2018.92 
Sidabutar, U. (2021). The effect of the audio-lingual method on students' speaking achievement. Jurnal Suluh Pendidikan, 9(1), 56-65.

Smith, M., \& Loewen, S. (2018). Situational Language Teaching. The TESOL Encyclopedia of English Language Teaching, 1-6. https://doi.org/10.1002/9781118784235.eelt0174.

Tassev, V. V. (2019). A review of the contribution to second language acquisition: A case-study of the grammar translation method and the audiolingual method. Research Journal Phranakhon Rajabhat: Social Sciences and Humanity, 14(2), 425-433.

Torgesen, J., Morgan, S., \& Davis, C. (1992). Effects of two types of phonological awareness training on word learning in kindergarten children. Journal of Educational Psychology, 84, 364-370. https://doi.org/10.1037/0022-0663.84.3.364

United Nations Children's Fund. (2018). Learning through play, strengthening learning through play in early childhood education programmes.

UNICEF Education Section.

United Nations Educational, Scientific and Cultural Organisation (UNESCO). (2014). Teaching and learning: achieving quality for all. Education for All Global Monitoring Report. https://unesdoc.unesco.org/ark:/48223/pf0000226662

Van de Pol, J., Volman, M., \& Beishuizen, J. (2010). Scaffolding in teacher-student interaction: A decade of research. Educational Psychology Review, 22, 271296. https://doi.org/10.1007/s10648-010-9127-6.

Van Kleeck, A. (1990). Emergent literacy: Learning about print before learning to read. Topics in Language Disorders, $\quad 10, \quad 25-45$. https://doi.org/10.1097/00011363-199003000-00004

Vilsack, C. (March 18, 2014). 250 million children in the world cannot read and USAID is doing something about it. https://blog.usaid.gov/2014/02/250-millionchildren-in-the-world-cannot-read-and-usaid-is-doingsomething-about-it/

Wagner, R., \& Torgesen, J. (1987). The nature of phonological processing and its causal role in the acquisition of reading skills. Psychological Bulletin, 101, 192-212. https://doi.org/10.1037/00332909.101.2.192

Wagner, R., Torgesen, J., Laughon, P., Simmons, K., \& Rashotte, C. (1993). Development of young readers' phonological processing abilities. Journal of Educational Psychology, 85, 83-103. https://doi.org/10.1037/0022-0663.85.1.83

Wang, Q. (2017). Comparison and contrast between the audiolingual method and total physical response to improve efficiency of college students english learning. Studies in Literature and Language, 15 (2), 38-40. http://dx.doi.org/10.3968/9868.

Wang, Q. (2014). Brief analysis of total physical response teaching method in second language teaching classrooms. Studies in Literature and Language, 15(2), 124-125. http://dx.doi.org/10.3968/9868

Wolk, L. (2015). Co-occurring stuttering and phonological difficulties in children: A model for therapy, Procedia - Social and Behavioral Sciences, 193, 333-334

Wullur, A. E. J., Liando, N. V. F., \& Rorimpandey, R. (2021). Improving students' motivation in studying english using audio-lingual method. Journal of English Language and Literature Teaching, 5(1). https://doi.org/10.36412/jellt.v5i1.2434

Caner, M. \& Yüksel, İ. (2014). Silent way. In Çelik, S. (Ed.). Approaches and principles in English as a foreign language (EFL) education. Eğiten.

Zainal, Z. (2007). Case study as a research method. Jurnal kemanusiaan, 5(1). 1-6

Zulpan. (2018). Total physical response (TPR): Its effect on students' achievement in reading procedure text. JEES (Journal of English Educators Society), 3(2). 205-214. https://doi.org/10.21070/jees.v3i2.1279. 